Corrigendum

\title{
Corrigendum to "Animal Models for the Study of Rodent-Borne Hemorrhagic Fever Viruses: Arenaviruses and Hantaviruses"
}

\author{
Joseph W. Golden, Christopher D. Hammerbeck, Eric M. Mucker, and Rebecca L. Brocato \\ Department of Molecular Virology, Virology Division, United States Army Medical Research Institute of Infectious Diseases, \\ Fort Detrick, MD 21702, USA \\ Correspondence should be addressed to Joseph W. Golden; joseph.w.golden.ctr@mail.mil \\ Received 7 October 2015; Accepted 15 October 2015
}

Copyright (C) 2015 Joseph W. Golden et al. This is an open access article distributed under the Creative Commons Attribution License, which permits unrestricted use, distribution, and reproduction in any medium, provided the original work is properly cited.

We identified an error in our review "Animal Models for the Study of Rodent-Borne Hemorrhagic Fever Viruses: Arenaviruses and Hantaviruses" [1]. In Section 2.6 "Development of Low Containment Arenavirus Animal Models through Adaptation of Pichinde Virus to Hamsters and Guinea Pigs" the sentence, "This may be owed to similar receptor usage as NW arenavirus of clade A usurp $\alpha$-dystroglycan for cellular entry, whereas clade B NW arenavirus bind transferrin receptor," is incorrect. The correct sentence is "Clade $\mathrm{C}$, but not clade $\mathrm{A}$, new world arenaviruses usurp $\alpha$-dystroglycan as their major receptor" (C. F. Spiropoulou, S. Kunz, P. E. Rollin, K. P. Campbell, and M. B. A. Oldstone, "New World arenavirus clade $\mathrm{C}$, but not clade $\mathrm{A}$ and $\mathrm{B}$ viruses, utilizes $\alpha$ dystroglycan as its major receptor," Journal of Virology, vol. 76 , no. 10, pp. 5140-5146, 2002). The receptor for the clade A viruses, including Pichinde virus, is unknown.

\section{References}

[1] J. W. Golden, C. D. Hammerbeck, E. M. Mucker, and R. L. Brocato, "Animal models for the study of rodent-borne hemorrhagic fever viruses: arenaviruses and hantaviruses," BioMed Research International, vol. 2015, Article ID 793257, 31 pages, 2015. 

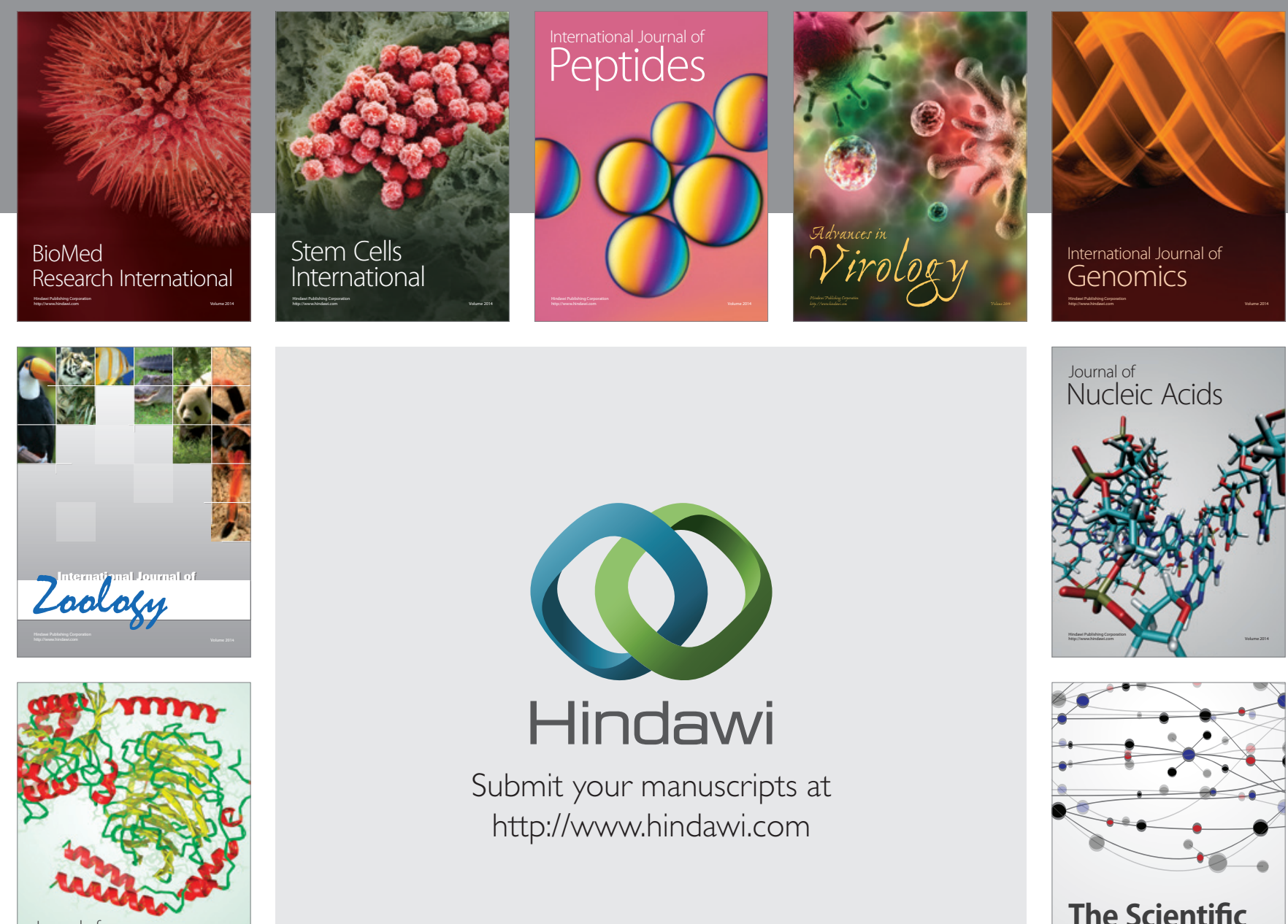

Submit your manuscripts at

http://www.hindawi.com

Journal of
Signal Transduction


The Scientific World Journal
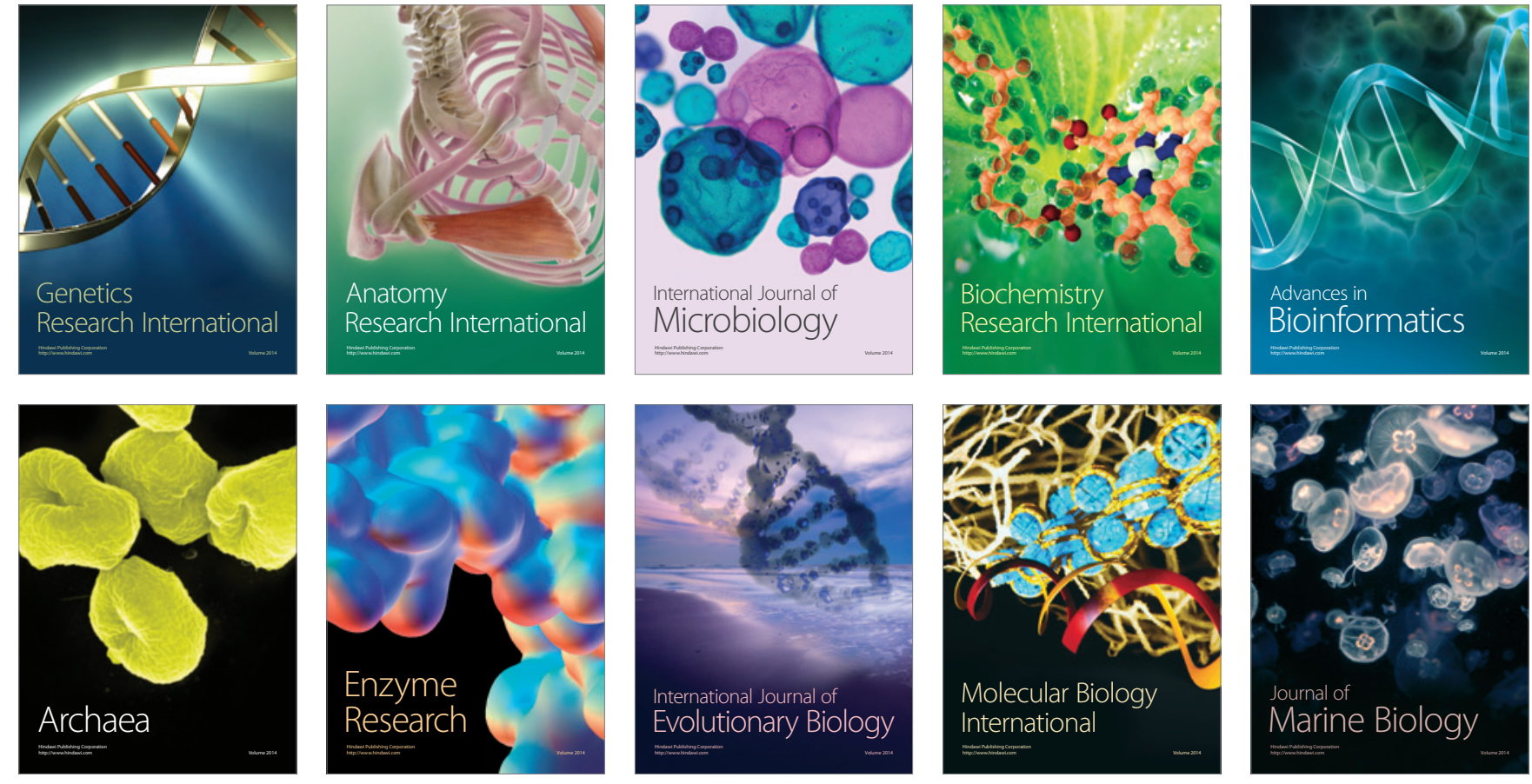